\title{
りんで栽培における共同防除作業従事者の農薬被曝量と 血中有機燐農薬の動態
}

臼谷三郎, 西山邦隆, 佐 藤 郁 雄 松浦喜美男, 沢田 幸 正 $^{*}$

\section{は じめに}

有機燐農薬は，稲作，果樹などの殺虫剂として永年 汎用されてきた。先年, パラチオンや有機塩素農薬な ど強毒性あるいは残留性の農薬が使用を禁止された り，制限されることによって，りんご栽培でもスミチ オン, サリチオンなどの低毒性有機燐農薬の使用が相 対的に増加している。

ただ，低毒性の農薬を取扱らがために防護がおろそ かになり, 防除従事者の農薬被曝量は, 強毒性の農薬 を使用していた時期よりもむしろ增大しているのでは ないかという懸念さえ生じている。

そこで,りんご栽培においてスピードスプレヤー（以 下 SS とする）によって共同防除作業（以下共防とす る）が行われる際に，オペレーターが吸入する農薬の 濃度を実測すると共に、防除従事者の健康調査を行 なって，農薬の血中濃度の消長などを中心とした野外 実験を行ない，いささか興味ある知見を得たので報告 する。

\section{I . 調 查 方 法}

i ）対象地域、被検者並びに調査時期

引前市千年地区を対象とした。本地域では有機燐農 薬による共防は， $6 ， 7 ， 8$ 月の 3 回と定められてお り, 1 回の防除日数は $2 \sim 3$ 日で, SS オペレーターは このらちの各 1 日に出役, 防除に当るのが慣行になっ ている。しかし，著者らが行なった全県的な調査 ${ }^{1) て ゙ ~}$ は, SS による防除の場合, 同一人の連日散布日数が 3

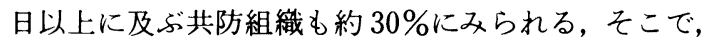
本調査においては, 全期間を通じて 3 日間, 連続して 防除に出役でき, 調查に協力し得る volunteer を募集

\footnotetext{
*弘前大学医学部公衆衙生学教室
} 受付 : 昭和 53 年 1 月 17 日
して被検者とした。 なお，調査は，昭和 48 年 7 月と 8 月に行なった。

ii ) 測定項目と方法

a ）吸入農薬量の測定

吸気または気中の農薬の捕集法としては, filter pad 法2), あるいは impinger 法があるが, 前者は散布 農薬の直接的な污染や樹葉などに付着した農薬の 2 次 污染をらけ易い欠点があり, 後者は機械吸引を原則と するため, 移動する場合には必要な動力源を得難い欠 点があった。そこで著者らは, impinger 一人一呼吸量 計システムで農薬を捕集することによって両者の短所 を補らことを試みた。即ち, 図 1 に示す如く, ガス代

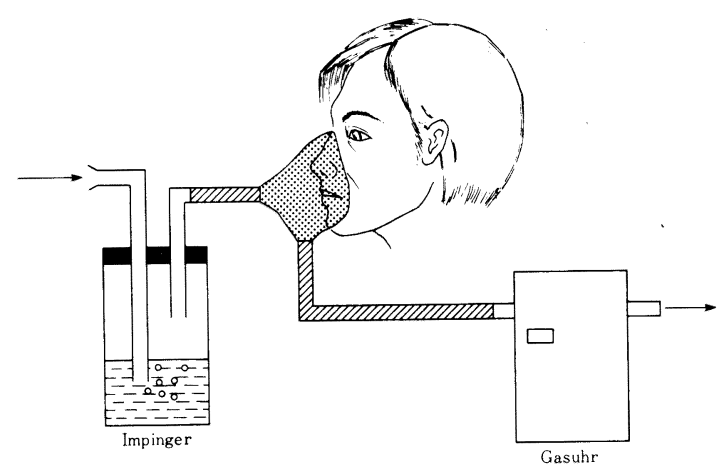

Figure 1. Measuring method for respiratory exposure concentration of the organophosphorus pesticide

謝測定用マスクの吸気弁の前方に改良 impinger 管 を, 呼気弁の後方に Max Planck の Respiratorische Gasuhr を接続した。本法によって, 気中農薬は吸気に よって impinger 管内で捕集され, 清浄化された空気 が体内を循環したのち呼出され，この際に呼気量が計 量される。なお, 正確に労作時の吸気量を知るには, 
この労作時のガス分析を行うことによって吸気量を算 出することもできるが，呼気量を吸気量の近似値とし て使用しても大差はない。

b ) 尿中 p-nitro-m-crezol (PNMC) 排泄量

尿中に排泄されたスミチオンの代謝物である PNMC をZn で還元し, o-crezolにより indophenol を生成, 発色させて比色定量し, その濃度を測定した 3)。

c ）血清中有機燐農薬の検出

渡部の方法4）を多少改変し, 表 1 に示す方法で測定 した。

Table 1. Procedure for extraction of organophosphorus pesticides in serum

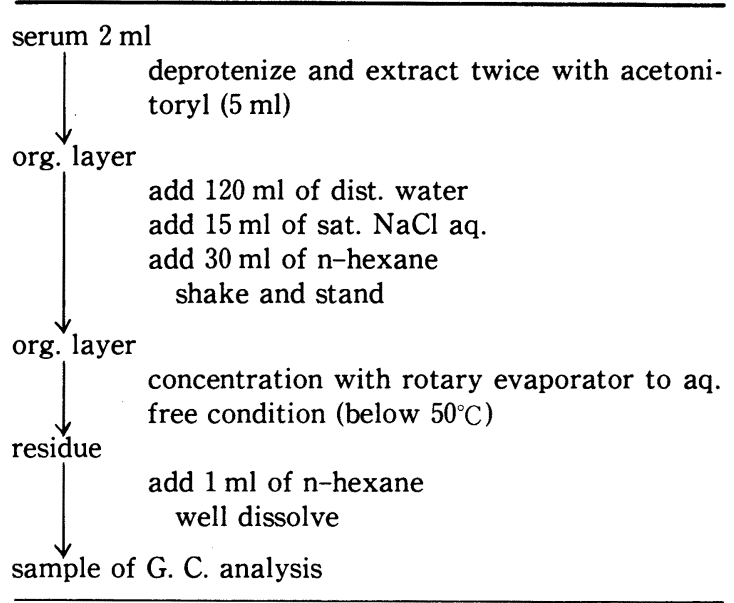

なお，ガスクロマトグラフ分析条件は次の如くであ る。

使用機器 : 島津 GC-3BFp 型

検出器 : 燐炎光光度検出器 (FPD)

カラム条件： シリコン ov-17 (充填剤)

$$
\text { ガラスカラム } 1.2 \mathrm{~m}
$$

流量条件： carrier gas $\mathrm{N}_{2} 0.7 \mathrm{~kg} / \mathrm{cm}^{2}$

$$
\text { detector gas } \begin{cases}\mathrm{H}_{2} & 2 \mathrm{~kg} / \mathrm{cm}^{2} \\ \text { air } & 1.3 \mathrm{~kg} / \mathrm{cm}^{2}\end{cases}
$$

温度条件： oven $190^{\circ} \mathrm{C}$

$$
\text { injection } 230^{\circ} \mathrm{C}
$$

本法による農薬の回収率は表 2 の如く, サリチオン では平均 $85.3 \%$ ，スミチオンでは, $84.6 \%$ であった。

d) 肝機能検査

血清トランスアミナーゼ(GOT, GPT)を ReitmanFrankel 法に基づくSTA-Test (Wako)により, ChE 活性値を Hesterine 一宮崎法によって測定した。
Table 2. Recovery rate of added pesticide from serum

\begin{tabular}{c|l|l}
\hline No. of sample & salithion & sumithion \\
\hline 1 & $90.5 \%$ & $76.4 \%$ \\
2 & 83.8 & 94.6 \\
3 & 79.7 & 80.0 \\
4 & 83.8 & 90.9 \\
5 & 90.5 & 83.6 \\
6 & 93.2 & 80.0 \\
7 & 81.1 & 87.3 \\
8 & 90.5 & 83.6 \\
9 & 89.2 & - \\
10 & 82.4 & - \\
\hline mean & $85.3 \%$ & $84.6 \%$
\end{tabular}

estimated from adding pesticide standard $(0.1 \mu \mathrm{g}$ respectively) to serum $2 \mathrm{ml}$ by same operating as Fig. 2 diagram

\section{II. 調查結 果}

\section{i ） SS による共防作業の労働状態}

共同防除班は, SS 1 台についてオペレーター2 名, 補助作業者（調剤, 調合係）1名から構成されている 場合が多い。防除作業は共防のための地域ブロック別 に設けられた眝水槽を基地として，補助作業者によっ て子め計量, 調整された薬剤を SS タンクに投入，水 で混合・稀釈して積載し，樹園地まで運搬して，散布 するといら単純作業を綝返しつつ, 順次, 場所を移動 してゆく。

なお,この際, オペレーターは作業服 (通称ツナギ), 麦わら帽子、ゴム手袋，ゴム長靴を着用するのが一般 的である。

いま，拘束時間内のタイムスタディを行ない，これ に既報文献値の RMR を適用して平均エネルギー代 謝率を求めると表 3 の如く，オペレーターで 1.37 , 補 助作業者では 1.05 と算定された。

ii） SS オペレーターの吸入農薬の濃度について オペレーターが SS に積載された約 $1000 l$ の水和 片の散布開始から終了するまでの1工程で吸入される 農薬量を測定した。なお，前述したように呼気量と吸 気量は近似するので, 呼気量で除して吸気中農薬浱度 $\left(\mathrm{mg} / \mathrm{m}^{3}\right)$ とした。結果を表 4 に示す。

8 測定例では $0.0058 \sim 0.0243 \mathrm{mg} / \mathrm{m}^{3}$ の幅に分布 し, その平均値土標準誤差は $0.01116 \pm 0.00191 \mathrm{mg} /$ $\mathrm{m}^{3}$ となった。

本値の水準であるならば，農薬製造工場における 8 時間，中等度労働に際しての環境抑制濃度の基準とさ 
Table 3. Working time and relative metabolic rate with SS operators and co-workers

\begin{tabular}{|c|c|c|c|c|}
\hline & & $\begin{array}{c}\text { Working time } \\
\text { (1) }\end{array}$ & $\begin{array}{c}\mathrm{RMR} \\
(2)\end{array}$ & $\begin{array}{l}\text { Amount of labour } \\
(1) \times(2)\end{array}$ \\
\hline \multirow{8}{*}{ 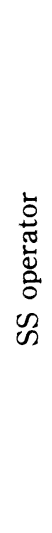 } & machine checking & 50 & 1.0 & 50.0 \\
\hline & driving along the road & 45 & 2.5 & 112.5 \\
\hline & compounding, loading of pesticide & 190 & 0.7 & 133.0 \\
\hline & meal, rest & 105 & 0.5 & 52.5 \\
\hline & spraying of pesticide & 290 & 2.0 & 580.0 \\
\hline & washing of SS & 10 & 1.5 & 15.0 \\
\hline & total & 690 & & 943.0 \\
\hline & mean relative metabolic rate $(\overline{\mathrm{RMR}})$ & 1.37 & & \\
\hline \multirow{11}{*}{ 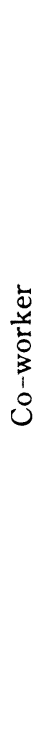 } & loading of pesticide & 30 & 3.5 & 105.0 \\
\hline & driving along the road & 25 & 2.5 & 62.5 \\
\hline & weighing of pesticide & 10 & 1.0 & 10.0 \\
\hline & meal, rest & 105 & 0.5 & 52.5 \\
\hline & preparation for spraying & 30 & 1.0 & 30.0 \\
\hline & compounding of pesticide & 195 & 0.7 & 136.5 \\
\hline & weighing and mixing of pesticide & 175 & 1.5 & 262.5 \\
\hline & book keeping, putting in order & 35 & 0.5 & 17.5 \\
\hline & rest & 55 & 0.5 & 37.5 \\
\hline & total & 680 & & 714.0 \\
\hline & mean relative metabolic rate $(\overline{\mathrm{RMR}})$ & 1.05 & & \\
\hline
\end{tabular}

れている ACGIH の許容濃度 ${ }^{5}$ ）(表 5 ) に比べると極 めて低い値であるといえる。

iii）血清中の有機燐農薬の消長

早朝, 作業前と散布終了後の 2 時点で肘静脈から約 $10 \mathrm{ml}$ 採血し, 前述の方法で測定した。

a ）血清中ス ミチオン濃度の推移

7 月上旬に, 800 倍スミチオン水和剤による防除の 際に測定した結果を表 6 に示す。

前回の散布からほぼ 1 力月後の血清であるが，散布 第 1 日目, 作業前の血清中にはスミチオンは勿論, 前 回に散布されたサリチオンも検出されていない。防除 作業終了後時の血清中には, 8 例中 6 例に $0.013 \sim 0$.
$061 \mu \mathrm{g} / 2 \mathrm{ml}$ の範囲でスミチオンが検出された。しか し, 翌朝の散布前血清では, 前日の作業終了時に痕跡 であった例をも含めて検出されていた 7 例のらち 4 例 がすでに不検出， 1 例が痕跡となり，他の 2 例も前日 測定時の $12 \% ， 64 \%$ に减少していた。

散布第 2 日目は降雨のため午後から共防は中止さ れ，さらに1日を拈いて散布が行われたが，このよう に約 40 時間後に当る散布前血清では対象者 8 例中 7 例が不検出， 1 例が痕跡程度に認められたにすぎな かった。

また，オペレーターに比べて調剤，運搬などの職種 の作業後における血中濃度が高い傾向を示している点 
Table 4. Respiration exposure concentration of SS operators in salithion spraying

\begin{tabular}{|c|c|c|c|c|c|c|c|c|}
\hline \multirow{2}{*}{ Date } & \multirow{2}{*}{$\begin{array}{l}\text { Measu- } \\
\text { red } \\
\text { No. }\end{array}$} & \multirow{2}{*}{$\begin{array}{l}\text { Measured } \\
\text { value } \\
\mathrm{A}(\mu \mathrm{g})\end{array}$} & \multirow{2}{*}{$\begin{array}{l}\text { Volume of } \\
\text { expired air } \\
\text { B }(l)\end{array}$} & \multirow{2}{*}{$\begin{array}{l}\text { Spraying } \\
\text { time } \\
\mathrm{C} \text { (min. } \\
\quad \mathrm{sec} .)\end{array}$} & \multicolumn{2}{|c|}{$\begin{array}{l}\text { Respiratory exposure } \\
\text { concentration }\end{array}$} & \multirow{2}{*}{$\begin{array}{l}\text { Atomospheric } \\
\text { condition }\end{array}$} & \multirow{2}{*}{ Notes } \\
\hline & & & & & $\mathrm{A} / \mathrm{B}\left(\mathrm{mg} / \mathrm{m}^{3}\right)$ & $\mathrm{A} / \mathrm{C}(\mathrm{mg} / \mathrm{hr})$ & & \\
\hline $\begin{array}{l}' 73 \\
8.4 .\end{array}$ & 2 & 2.55 & 258.4 & 18.20 & 0.0134 & 0.0116 & $\begin{array}{l}\text { Air tempera- } \\
\text { ture } 28.6^{\circ} \mathrm{C} \\
\text { Air hunidity } \\
69 \% \\
\text { Air velocity } \\
0.4 \sim 1.1 \mathrm{~m} / \mathrm{sec} .\end{array}$ & $\begin{array}{l}\text { Type of trac- } \\
\text { tor-self-power } \\
\text { air blast eqip- } \\
\text { ment }\end{array}$ \\
\hline $\begin{array}{l}73 \\
8.5 .\end{array}$ & 2 & 2.63 & 279.2 & 17.35 & 0.0095 & 0.0083 & $\begin{array}{l}\text { Air tempera- } \\
\text { ture } 30.2^{\circ} \mathrm{C} \\
\text { Air humidity } \\
\quad 63 \% \\
\text { Air velocity } \\
0.3 \sim 1.7 \mathrm{~m} / \mathrm{sec} \text {. }\end{array}$ & \\
\hline \multirow{2}{*}{$\begin{array}{l}' 73 \\
8.6 .\end{array}$} & 1 & 2.70 & $\begin{array}{l}307.4 \\
285.8\end{array}$ & $\begin{array}{l}23.05 \\
18.40\end{array}$ & $\begin{array}{l}0.0088 \\
0.0058\end{array}$ & $\begin{array}{l}0.0070 \\
0.0053\end{array}$ & \multirow{2}{*}{$\begin{array}{l}\text { Air tempera- } \\
\text { ture } 27.2^{\circ} \mathrm{C} \\
\text { Air humidity } \\
\qquad 2 \% \\
\text { Air velocity } \\
0 \sim 0.5 \mathrm{~m} / \mathrm{sec} \text {. } \\
\text { Air tempera- } \\
\text { ture } 28.3^{\circ} \mathrm{C} \\
\text { Air humidity } \\
\quad 75 \% \\
\text { Air velocity } \\
0.5 \sim 1.2 \mathrm{~m} / \mathrm{sec} .\end{array}$} & \multirow[t]{2}{*}{$\begin{array}{l}\text { Type of trac- } \\
\text { tor-drown-power } \\
\text { air blast equip- } \\
\text { ment }\end{array}$} \\
\hline & 3 & 3.53 & 331.5 & 20.40 & $\begin{array}{l}0.0106 \\
0.0243\end{array}$ & $\begin{array}{l}0.0102 \\
0.0217\end{array}$ & & \\
\hline $\begin{array}{l}\text { Mean } \\
\text { dard ei }\end{array}$ & stan- & $\begin{array}{l}3.258 \\
\pm 0.613\end{array}$ & $\begin{array}{r}288.78 \\
\pm 8.48\end{array}$ & $\begin{array}{l}18.56 \\
\pm 5.3\end{array}$ & $\begin{array}{l}0.01116 \\
\pm 0.00191\end{array}$ & $\begin{array}{l}0.01018 \\
\pm 0.00167\end{array}$ & & \\
\hline
\end{tabular}

Table 5. Threshold limit value for organophosphorus pesticides by ACGIH recommendation

\begin{tabular}{|c|c|c|}
\hline $\begin{array}{c}\text { Name } \\
\text { of pesticide }\end{array}$ & $\begin{array}{l}\text { Threshold limit } \\
\text { value }\end{array}$ & recommedation \\
\hline $\begin{array}{l}\text { Dysyston } \\
\text { EPN } \\
\text { DDVP } \\
\text { TEPP } \\
\text { Malathion } \\
\text { Phorate } \\
\text { Phosdrin } \\
\text { Demeton } \\
\text { Diazinon } \\
\text { Dibrom }\end{array}$ & $\begin{array}{l}0.1 \\
0.5 \\
1 \\
0.05 \\
10 \\
0.05 \\
0.1 \\
0.1 \\
0.1 \\
3\end{array}$ & $\begin{array}{l}\text { recommendated } \\
\text { value of } 1975\end{array}$ \\
\hline
\end{tabular}

が注目されるが，最高値でも $0.061 \mu \mathrm{g} / 2 \mathrm{ml}$ の程度に 止まっている。

b ）血清中サリチオン濃度の推移

スミチオンの散布から約 1 力月後の 8 月上旬にサリ チオン 1000 倍液として散布された際の血中サリチオ ン濃度の推移を表 7 に示す。

第 1 日目の作業前血清では全員が不検出であったも のが, 作業後血清では $0.006 \sim 0.043 \mu \mathrm{g} / 2 \mathrm{ml}$ の範囲で 全員に検出された。

翌日, 作業前には 6 例の $5 ち 1$ 例が前日作業終了時 に検出された水準の $54 \%$ の濃度で検出されたが，他の 3 例は痕跡, 2 例は不検出となっている。

なお，2 日目の作業後の血中サリチオン濃度が初日 の作業後の值よりも高值を示したのは 1 例のみであっ て，他はすべて低い値となっている。 
Table 6. Changes of Sumithion concentration in serum

$\mu \mathrm{g} / \operatorname{serum} 2 \mathrm{ml}$

\begin{tabular}{|c|c|c|c|c|c|c|c|c|}
\hline \multirow{2}{*}{$\begin{array}{l}\text { Sub. } \\
\text { No. }\end{array}$} & \multirow{2}{*}{ Age } & \multirow{2}{*}{$\begin{array}{c}\text { Type of } \\
\text { occupation }\end{array}$} & \multicolumn{2}{|c|}{ 73. 7. 1 . } & \multicolumn{2}{|c|}{ 73. 7.2.} & \multicolumn{2}{|c|}{ 73. 7. 4.} \\
\hline & & & before task & after task & before task & after task & before task & after task \\
\hline 1 & 29 & Operator & ND & $\phi$ & ND & & ND & $\phi$ \\
\hline 2 & 43 & " & ND & 0.013 & $\phi$ & suspend & ND & $\phi$ \\
\hline 3 & 30 & " & ND & 0.020 & ND & & ND & 0.032 \\
\hline 4 & 26 & " & ND & 0.014 & $\mathrm{ND}$ & & ND & $\phi$ \\
\hline 5 & 36 & " & ND & $\phi$ & ND & & ND & $\phi$ \\
\hline 6 & 39 & Co-worker & ND & - & - & & ND & $\phi$ \\
\hline 7 & 40 & " & ND & 0.061 & 0.0075 & & ND & 0.007 \\
\hline 8 & 49 & " & ND & 0.022 & - & & - & 0.013 \\
\hline 9 & 19 & Transpoter & ND & 0.042 & 0.027 & & $\phi$ & 0.021 \\
\hline
\end{tabular}

ND : non-detect

Table 7. Changes of Salithion concentration in serum

$\mu \mathrm{g} / \operatorname{serum} 2 \mathrm{ml}$

\begin{tabular}{|c|c|c|c|c|c|c|}
\hline \multirow{2}{*}{$\begin{array}{l}\text { Sub. } \\
\text { No. }\end{array}$} & \multirow{2}{*}{ Age } & \multirow{2}{*}{$\begin{array}{c}\text { Type of } \\
\text { occupation }\end{array}$} & \multicolumn{2}{|c|}{ 73. 8. 5.} & \multicolumn{2}{|c|}{ 73. 8. 6 . } \\
\hline & & & before task & after task & before task & after task \\
\hline 1 & 29 & Operator & ND & 0.026 & 0.014 & 0.005 \\
\hline 2 & 43 & " & ND & - & $\phi$ & 0.0025 \\
\hline 3 & 30 & "I & ND & 0.006 & $\phi$ & 0.029 \\
\hline 4 & 26 & " & ND & 0.016 & ND & 0.008 \\
\hline 5 & 36 & "I & ND & 0.013 & - & - \\
\hline 6 & 39 & Co-worker & ND & 0.043 & $\phi$ & 0.019 \\
\hline 7 & 41 & " & ND & 0.018 & ND & 0.011 \\
\hline 8 & 49 & " & ND & 0.033 & - & 0.006 \\
\hline 9 & 19 & Transpoter & ND & 0.017 & $\phi$ & 0.008 \\
\hline & & & & & $\begin{array}{l}\phi: \text { :und } \\
\text { ND : n }\end{array}$ & \\
\hline
\end{tabular}

iv) 尿中代謝物（PNMC）からみた被曝量の職種別 差異について

SS オペレーター11名, 補助作業者 7 名, 運搬 1 名計 19 名を対象として, 早朝, 作業前に放尿, 以後, 翌朝 同時刻までの 24 時間尿を蓄尿させ, その中の PNMC を定量した。結果は表 8 の如くで，その群別平均値士 標準誤差は, 次の如くである。 オペレーター：0.01333土0.00243 mg/dl

補助作業者 : $0.0229 \pm 0.00416 \mathrm{mg} / \mathrm{dl}$

平均値に群間差はないが, 補助作業者の方がオぺ レーターよりやや大きい傾向を示している。なお, PNMC と之ミチオンの分子量比から得られた PNMC よりスミチオン量に換算した値, 並びにクレ アチニン量によって尿の濃度補正を行った值を併せ同 表に示したが,これらも同じ傾向を示している。
このことは, 前述した血中の農薬濃度の職種別傾向 とも一致している。

v）共防作業に伴ら血清酵素の変化

前述した血清の一部で, GOT, GPT, ChE 活性值を 測定した。その推移を図 2,3 に示したが, 初日, 作 業前にトランスアミナーゼが高かった 1 例が，2 日目， 作業前に急増した例を除いて概して異常は認められな かった。

群別平均値士標準誤差を算出すると表 9 の如くであ る。

なお, 血清中有機燐農薬濃度と血清酵素值の較差(作 業後値一前值）との相関を検討すると表 10 の如くで, スミチオン散布時の GPT で有意の相関を得た以外 は，両者間に有意の相関は認められなかった。 
Table 8. Comparison with urinary excreation of PNMC between SS operator and co-worker

\begin{tabular}{|c|c|c|c|c|c|c|c|}
\hline \multirow[t]{2}{*}{$\begin{array}{l}\text { Sub. } \\
\text { No. }\end{array}$} & \multirow[t]{2}{*}{ Age } & \multirow{2}{*}{$\begin{array}{c}\text { Type } \\
\text { of } \\
\text { occupation }\end{array}$} & \multirow{2}{*}{$\begin{array}{l}\text { PNMC } \\
\text { volues } \\
(\mathrm{mg} / \mathrm{dl})\end{array}$} & \multicolumn{2}{|c|}{$\begin{array}{c}\text { Calculated in Sumithion } \\
\text { equivalent from } \\
\text { PNMC }\end{array}$} & \multirow{2}{*}{$\begin{array}{l}\text { Urinary } \\
\text { creatinine } \\
(\mathrm{mg} / \mathrm{dl})\end{array}$} & \multirow{2}{*}{$\begin{array}{c}\begin{array}{c}\text { Sumithion } \\
(\mathrm{mg} / \mathrm{dl})\end{array} \\
\text { Creatinine } \\
(\mathrm{mg} / \mathrm{dl}) \\
\times 10^{4}\end{array}$} \\
\hline & & & & $\mathrm{mg} /$ day & $\mathrm{mg} / \mathrm{dl}$ & & \\
\hline 1 & 29 & \multirow{11}{*}{ SS operator } & 0.0143 & 0.312 & 0.0259 & 140.2 & 1.85 \\
\hline 2 & 43 & & 0.0085 & 0.149 & 0.0154 & 109.5 & 1.41 \\
\hline 3 & 30 & & 0.0255 & 0.778 & 0.0462 & 69.5 & 6.65 \\
\hline 4 & 26 & & 0.0110 & 0.358 & 0.0199 & 78.1 & 2.55 \\
\hline 5 & 36 & & 0.0300 & 1.006 & 0.0544 & 105.9 & 5.14 \\
\hline 6 & 19 & & 0.0053 & 0.124 & 0.0096 & 125.4 & 0.77 \\
\hline 7 & 37 & & 0.0075 & 0.148 & 0.0136 & 141.7 & 0.96 \\
\hline 8 & 52 & & 0.0030 & 0.091 & 0.0054 & 85.6 & 0.63 \\
\hline 9 & 35 & & 0.0143 & 0.303 & 0.0259 & 74.2 & 3.49 \\
\hline 10 & 41 & & 0.0085 & 0.270 & 0.0154 & 76.8 & 2.01 \\
\hline 11 & 28 & & 0.0187 & 0.447 & 0.0339 & 129.9 & 2.61 \\
\hline \multicolumn{3}{|c|}{ Mean \pm standard error } & $\begin{array}{r}0.01333 \\
\pm 0.00243 \\
\end{array}$ & $\begin{array}{r}0.3624 \\
\pm 0.0829 \\
\end{array}$ & $\begin{array}{r}0.02415 \\
\pm 0.00440 \\
\end{array}$ & $\begin{array}{l}103.35 \\
\pm 7.98 \\
\end{array}$ & $\begin{array}{r}2.552 \\
\pm 0.544 \\
\end{array}$ \\
\hline 12 & 39 & \multirow{7}{*}{$\begin{array}{l}\text { SS } \\
\text { co-worker }\end{array}$} & 0.0243 & 0.647 & 0.0440 & 103.9 & 4.23 \\
\hline 13 & 40 & & 0.0187 & 0.515 & 0.0339 & 90.9 & 3.73 \\
\hline 14 & 49 & & 0.0470 & 1.004 & 0.0851 & 107.3 & 7.93 \\
\hline 15 & 50 & & 0.0276 & 0.585 & 0.0500 & 122.6 & 4.08 \\
\hline 16 & 48 & & 0.0130 & 0.345 & 0.0236 & 78.1 & 3.02 \\
\hline 17 & 23 & & 0.0143 & 0.269 & 0.0259 & 127.2 & 2.04 \\
\hline 18 & 31 & & 0.0155 & 0.278 & 0.0281 & 141.7 & 1.98 \\
\hline \multicolumn{3}{|c|}{ Mean \pm standard error } & $\begin{array}{r}0.02291 \\
\pm 0.00416\end{array}$ & $\begin{array}{r}0.5204 \\
\pm 0.0911\end{array}$ & $\begin{array}{r}0.04151 \\
\pm 0.00753\end{array}$ & $\begin{array}{l}110.24 \\
\pm 7.67\end{array}$ & $\begin{array}{r}3.859 \\
\pm 0.704\end{array}$ \\
\hline 19 & 19 & Transporter & 0.0692 & 0.953 & 0.1254 & 165.0 & 7.60 \\
\hline
\end{tabular}



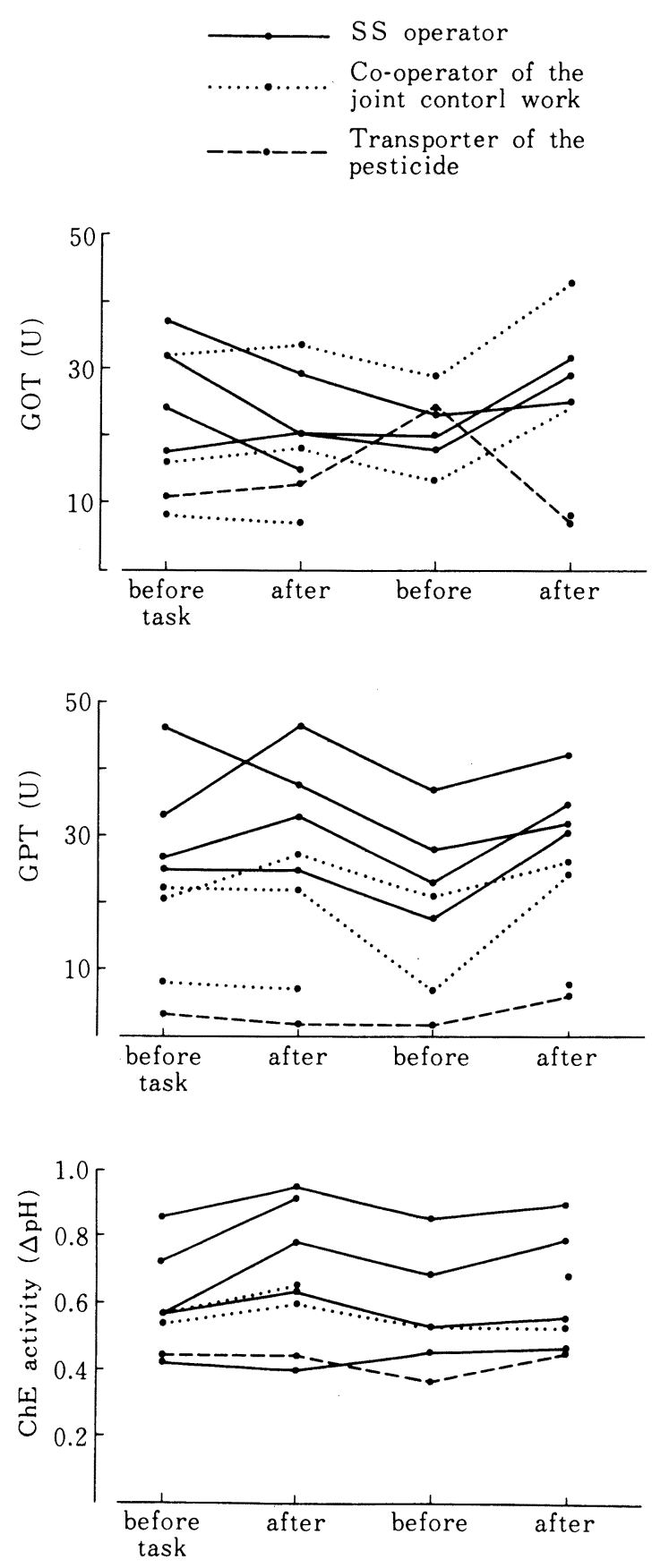

Figure 2.

Changes in serum GOT, GPT and $\mathrm{ChE}$ activity before and after the task on each day by Sumithion spraying
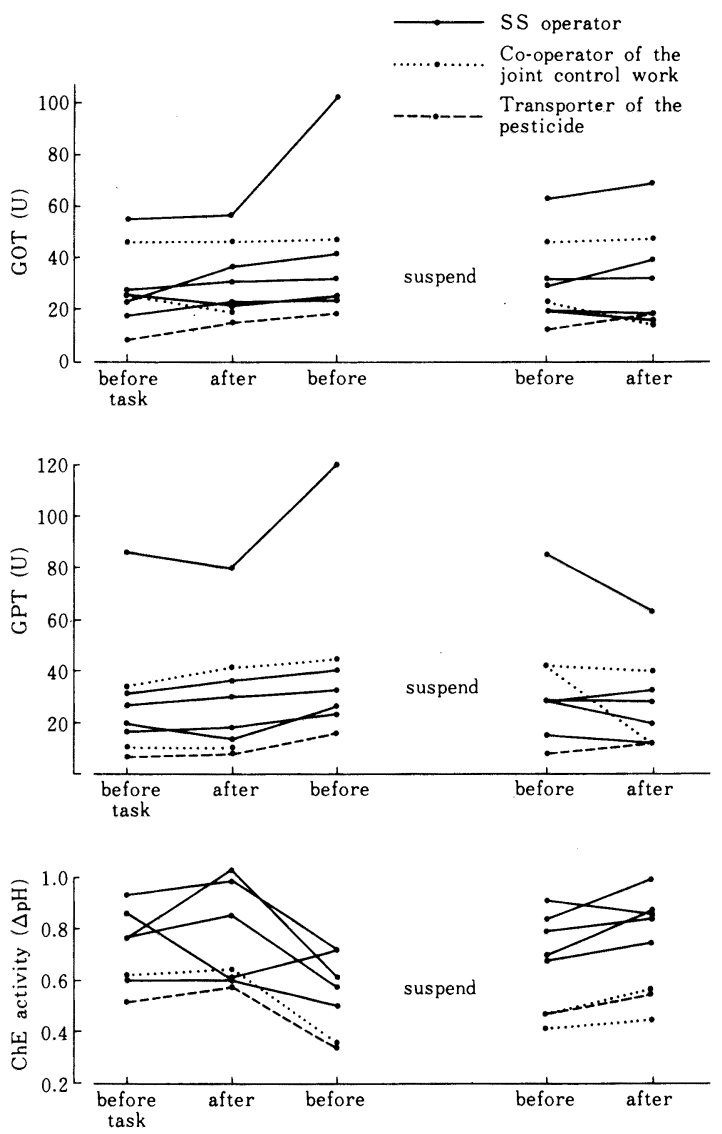

Figure 3.

Changes in serum GOT, GPT and $\mathrm{ChE}$ activity before and after the task on each day by Salithion spraying

\section{III. 考察}

SS による農薬散布作業におけるオペレーターの農 薬吸入量や吸入濃度などについては，これまでわが国 では実測されていない。H.R.Wolfe ら ${ }^{6)}$ は, 果樹園で $0.03 \sim 0.12 \%$ の濃度の有機燐農薬を含む 11 種類の農 薬を tractor-drown power air blast equipment を使 用して散布した際のオペレーターの respiratory exposure を測定し，それぞれの農薬の平均値の範囲は $0.02 \sim 0.26 \mathrm{mg} / \mathrm{hr}$ であったと述べている。また， Z. Jegier ${ }^{7)}$ は, air blast machines hauled by tractor で 果樹園に散布した malathion (25\% wettable powder, 1-2. 5LB/100gal.) の例では, 4 例の平均値であるが, $0.08 \mathrm{mg} / \mathrm{hr}$ であったとしている。

著者らの測定値を $\mathrm{mg} / \mathrm{hr}$ に換算すると $0.0102 \pm 0$. 
Table 9. Mean \pm standard deviations of serum enzymes measured before and after the task on each day

(SS operator)

Period of Sumithion spraying (5 men)

\begin{tabular}{|c|c|c|c|c|c|c|}
\hline & & \multicolumn{2}{|c|}{$1 /$ VII } & \multirow{2}{*}{$\frac{2 / \mathrm{VII}}{\text { before }}$} & \multicolumn{2}{|c|}{$4 /$ VII } \\
\hline & & before & after & & before & after \\
\hline GOT & $\begin{array}{l}\text { Mean } \\
\text { S. D. }\end{array}$ & $\begin{array}{l}30.2 \\
12.8\end{array}$ & $\begin{array}{l}34.0 \\
12.7\end{array}$ & $\begin{array}{l}44.6 \\
29.5\end{array}$ & $\begin{array}{l}33.0 \\
15.8\end{array}$ & $\begin{array}{l}35.2 \\
18.8\end{array}$ \\
\hline GOT & $\begin{array}{l}\text { Mean } \\
\text { S. D. }\end{array}$ & $\begin{array}{l}36.2 \\
25.4\end{array}$ & $\begin{array}{l}35.8 \\
23.6\end{array}$ & $\begin{array}{l}48.4 \\
36.3\end{array}$ & $\begin{array}{l}37.2 \\
24.5\end{array}$ & $\begin{array}{l}31.2 \\
17.2\end{array}$ \\
\hline $\begin{array}{l}\text { ChE } \\
\text { activity } \Delta \mathrm{pH}\end{array}$ & $\begin{array}{l}\text { Mean } \\
\text { S. D. }\end{array}$ & $\begin{array}{l}0.79 \\
0.11\end{array}$ & $\begin{array}{l}0.81 \\
0.18\end{array}$ & $\begin{array}{l}0.62 \\
0.08\end{array}$ & $\begin{array}{l}0.76 \\
0.11\end{array}$ & $\begin{array}{l}0.84 \\
0.11\end{array}$ \\
\hline
\end{tabular}

Period of Salithion spraying

\begin{tabular}{|c|c|c|c|c|c|}
\hline & & \multicolumn{2}{|c|}{$5 /$ VII } & \multicolumn{2}{|c|}{$6 /$ VII } \\
\hline & & before & after & before & after \\
\hline GOT & $\begin{array}{l}\text { Mean } \\
\text { S. D. }\end{array}$ & $\begin{array}{r}27.5 \\
7.4\end{array}$ & $\begin{array}{r}25.3 \\
5.4\end{array}$ & $\begin{array}{r}22.5 \\
4.2\end{array}$ & $\begin{array}{r}31.3 \\
5.5\end{array}$ \\
\hline GPT & $\begin{array}{l}\text { Mean } \\
\text { S. D. }\end{array}$ & $\begin{array}{r}32.8 \\
8.2\end{array}$ & $\begin{array}{r}35.8 \\
8.0\end{array}$ & $\begin{array}{r}26.5 \\
7.0\end{array}$ & $\begin{array}{r}35.0 \\
4.3\end{array}$ \\
\hline $\begin{array}{l}\text { ChE } \\
\text { activity } \Delta \mathrm{pH}\end{array}$ & $\begin{array}{l}\text { Mean } \\
\text { S. D. }\end{array}$ & $\begin{array}{l}0.72 \\
0.15\end{array}$ & $\begin{array}{l}0.87 \\
0.18\end{array}$ & $\begin{array}{l}0.76 \\
0.16\end{array}$ & $\begin{array}{l}0.82 \\
0.17\end{array}$ \\
\hline
\end{tabular}

Table 10. Correlation coefficient between concentration of organophosphorus pesticide in serum and values of serum enzyme

\begin{tabular}{c|c|c}
\hline & Sumithion & Salithion \\
\hline GOT & $0.064 \quad(16)$ & $0.049(15)$ \\
\hline GPT & $0.546^{*} \quad(16)$ & $-0.464(15)$ \\
\hline ChE & $0.015 \quad(16)$ & $-0.277(15)$
\end{tabular}

( ) Number of persons examined * $\mathrm{P}<0.05$

$0017 \mathrm{mg} / \mathrm{hr}$ となり, 両者の值よりもやや低い。

一般に農薬の吸入濃度は散布機器の馬力, 気象条件, 果樹の種類や栽植状況, 薬剂の種類や剂型, 測定方法 など多くの要素に左右されるが，この程度の吸入農薬 の濃度ならば, ACGIH の許容濃度と比較すると明ら かに低く, 1 回の respiratory exposure はそれ程問題 にするに足らないと考える。

このような吸入濃度の現状での共防従事者の血中有
機燐農薬の濃度は73 例の実測值のらち最高値が 0.061 $\mu \mathrm{g} / 2 \mathrm{ml}$ のレベルであって, 渡部 ${ }^{8)}$, 石川 $5^{9)}$, 工藤 $5^{10)}$ が報告した值に比べて $1 / 10$ のオーダーの低い值 であった。

また，血中有機燐農薬も比較的短時間で血中から消 退しておりこれまで動物実験で血中や各缄器からの 消退が早く，生体内残存は短期間である結果とする11) 15)を労働現場で実証したものと考える。 
なお，サリチオン散布の例でみられたよらに，2 日 連続散布でも， 2 日目作業後の血中有機燐農薬の濃度 は初日のそれに比べて低下したものが多く, 現下の労 働状況では，2 日連続散布でも問題とされることは少 ないと思われるが，今後とも例数を増して検討してい きたい。

ただ, 血清 GOT, GPT の高い 1 例が, 自覚的には著 変は認めなかったが, 各々 2 日目の午前に急増した。 従って, オペレーターとして出役する者は共防作業が 始まる以前に健康チェックを行い，オペレーターとし ての適性に合らもののみ就労させるといら管理方針が 望ましいことを示しているよらに考える。

職種別には, オペレーターよりもむしろ補助作業者 や農薬を運搬するものの血中有機燐農薬濃度が高く, かつ, 農薬の尿中代謝物濃度も高いといら結果が得ら れた。

これは, オペレーターの場合, 曝露される農薬は 800 〜1000 倍水和剂が主であるのに対して, 補助作業者は 混和, 希釈の準備作業として農薬原末を取り扱らこと, 運搬係は農薬を倉庫から自動車へ積み込み，現場で荷 おろしするといら過程で付着していた農薬を吸入する 機会が多いことなど，いずれも一時的に高濃度曝露を らけるためと考えられる。従って，オペレーター以上 に, 補助作業者や運搬係に農薬危害防止のための教育 が必要であると言えよう。

\section{IV. 結 論}

りんご栽培で，スピードスプレヤー（SS）による共 同防除が行われた際の農薬被曝量, 血液中有機燐農薬 濃度, 血清酵素の消長などを観察し, 大要次の如き結 論を得た。

1. SS オペレーターが低毒性有機燐農薬（散布時, $800 \sim 1000$ 倍水和剂）の散布中に吸入する吸気中農薬 濃度の平均値士標準誤差は $0.01116 \pm 0.00191 \mathrm{mg} / \mathrm{m}^{3}$ であった。

2. 散布作業を連日行なわせ, 作業前後の血清中有 機燐農薬の濃度を測定した結果，オペレーターでの最 高濃度は $0.032 \mu \mathrm{g} / 2 \mathrm{ml}$, 補助作業者では $0.061 \mu \mathrm{g} /$ $2 \mathrm{ml}$ であった。また，作業後に検出された血中農薬は， 翌朝にはほとんどが痕跡又は不検出となっており，多 少農薬が認められた者も，約 40 時間共同防除作業を中 止することにより，血中の農薬濃度は痕跡又は不検出 に変化していた。

これらのことは, 前述した程度の吸気中農薬濃度で あり, 健康状態に異常がない限り，比較的早期に代謝 され，血中から消失することを示しているものと思わ
れる。

3. 2 日間連続散布を行なった際の血清中有機燐濃 度には，蓄積，増加する傾向は認められなかった。

4.共同防除作業を含む 24 時間尿を採取し, PNMC 排泄量を職種別に比較すると

オペレーター群 : $0.01333 \pm 0.00243 \mathrm{mg} / \mathrm{dl}$

補助作業者群 $: 0.02291 \pm 0.00416 \mathrm{mg} / \mathrm{dl}$ となり，群間に有意の差はないが，概して，後者の方 が多い傾向が得られた。

5 . 血中農薬濃度と GOT, GPT, $\mathrm{ChE}$ 活性值の变動 との間には，有意な相関関係は得られなかっだ。

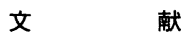

1) 臼谷三郎, 西山邦隆, 佐藤郁雄 : 東北積雪地帯農民の労働と 保健に関する研究，第 5 報，共同防除従事者の生体負担につ いて, 弘前医学, 27, 356 368, 1975.

2 ) Willian F.Durham \& Homer R.Wolfe B.S. : Measurement of the exposure of workers to pesticides, Bull. Wld. Hlth. Org., 26, 75〜91, 1962.

3 ) 厚生省 : 有機燃製剂の薬理作用と化学的性質, $14 \sim 16$, 昭和 30 年.

4) Watanabe Shinobu: Detection of organophosphate pesticide in blood serum from the patients of acute and chronic pesticide poisonings and its clinical significance, Tohoku J. exp. Med ., 107, 301 302, 1972.

5 ) ACGIH : 労衝衛生, 17, 20 25 1976.

6 ) H.R. Wolfe \& J. F. Armstrong : Exposure of spraymen to pesticides, Arch. Environ. Health, 25, 29 $\sim 31,1972$.

7 ) Z. Jegier: Health hazards in insecticide spraying of crops. Arch. Environ. Health, 8, 670 674, 1964.

8 ) 渡部 忍: 慢性農薬有機燐中毒症を疑わしめる場合の血清 中農薬, 有機燐検出の意義, 農村医学, $23,42 \sim 49,1974$.

9 ) 石川 哲: 公害と眼, 有機燐と眼, 日本眼科学会誌, 77,1835 $\sim 1886,1973$.

10 ）工藤尚義：農薬中毒の病態生理, 有機燐慢性中毒の実態と臨 床と診断（15 報)，第 22 回日本農村医学会総会抄録, 196 $\sim 197,1973$.

11 ) Miyamoto J., Sato Y., Kadota I., Fujinami A. and Endo M., Studies on the mode of action of organophosphorus compounds, Agr. Biol. Chem., 27, 381 389, 1963.

12 ) Bourke, J. B.,Broderik, E. J., Hackler, L. R. and Lippold, P. C. : Comparative metabolism of Malathion " $\mathrm{C}$ in plants and animals, J. Agr. Chem., 16, 585 589, 1969.

13 ) 大川秀郎, 江藤守, 大島康義: 殺虫剂サリチオン（2-methoxy-4H-1, 3,2, - benzodioxa phosphorine-2-. sulfide）の代謝と毒性, 日本応用動物昆虫学会誌，14，191 $\sim 194,1970$.

14 ) 浅沼信治：有機燐剤の生体残留に関する実験的研究, 農村医 学, 22, 282 283, 1973.

15 ) 高橋政教, 井口弘三, 笠川宏子, 井司郎, 石見貞次, 木村正 方：有機りン農薬の生体内残留に関する実験的研究, 農村医 学, 24, 601 606, 1975. 


\title{
Studies on the Amount of Exposure to Pesticides and Blood Levels of Organophosphorus Pesticides of Farmers Engaging in Joint Control Works over Apple Orchards
}

\author{
Saburo USUTANI, Kunitaka NISHIYAMA, Ikuo SATO, \\ Kimio MATSUURA and Yukimasa SAWADA \\ Department of Public Health, Hirosaki University School of Medicine \\ (Chief: Prof. S. Usutani), Hirosaki, Japan
}

The concentration of pesticide that was inspired by speed sprayer (SS) operators in spraying a low toxic organophosphorus pesticide ( 800 - fold to 1000 -fold dilutions of wettable agent) were measured by the impinger-one respirator-per man measuring system. The mean \pm standard error was $0.01116 \pm 0.00191 \mathrm{mg} / \mathrm{m}^{3}$.

The operators were made to perform the spraying task every day, and the organophosphorus pesticide concentration in the serum was gas-chromatographically measured before and after the task on each day. The maximum concentration after daily task was $0.032 \mu \mathrm{g} / 2 \mathrm{ml}$ in an operator, and $0.061 \mu \mathrm{g} / 2 \mathrm{ml}$ in an assistant. The concentration was already trace or undetectable in many of them the following morning.

No apparent tendency for the pesticide to be accumulated was observed even in the operators after spraying the pesticide for 2 consecutive days.

The 24-hour urine was collected from each subject to measure the output of PNMC (p-nitro-m-crezol). The output tended to be greater in the assistants than in the operators. This finding may be attributed to the fact that the assistants are trasiently exposed to high concentrations of the pesticide in powder form. 